\title{
The effect of breed on the chemical composition and fatty acid profile of the Longissimus dorsi muscle of Brazilian beef cattle
}

\author{
J.M. Prado, I.N. Prado ${ }^{1,4}$, J.V. Visentainer ${ }^{2}$, P.P. Rotta ${ }^{1}$, D. Perotto ${ }^{3}$, \\ J.L. Moletta ${ }^{3}$, I.M. Prado ${ }^{1}$ and T. Ducatti ${ }^{1}$
}

\author{
State University of Maringá, \\ ${ }^{1}$ Department of Animal Science, \\ ${ }^{2}$ Department of Graduate Chemistry \\ Av. Colombo, 5790, CEP 87020-900 Maringá, Paraná, Brazil \\ ${ }^{3}$ IAPAR Agronomic Institute of Paraná \\ CEP 82630-900, Curitiba, Paraná, Brazil
}

(Received 17 July 2008; revised version 2 December 2008; accepted 20 March 2009)

\begin{abstract}
The study was conducted to evaluate the chemical composition and fatty acid profile of the Longissimus dorsi muscle of first (PUR1) and second (PUR2) generations of Purunã-breed cattle, and compare them to their ancestral generations (PUR). Thirty-nine young bulls with an average initial weight of $236 \mathrm{~kg}$ and initial age of 10 months were used. The animals were slaughtered at the age of 16 months with an average final weight of $464 \mathrm{~kg}$. The content of water, ash, crude protein and total cholesterol in the muscles were similar $(\mathrm{P}>0.05)$ among the different genetic groups. The levels of total intramuscular fat were higher $(\mathrm{P}<0.05)$ for PUR in comparison to PUR1 and PUR 2. The percentage shares of 14:0, 14:1 n-7 and 16:0 fatty acids were higher $(\mathrm{P}<0.05)$ as a percentage of total fatty acids in PUR2 and PUR in comparison to PUR1. Thus, the 22:6n-6 ratios were greatest $(\mathrm{P}<0.05)$ for the PUR1 genetic group. The lowest $(\mathrm{P}<0.05)$ percentage was observed in PUR. There were no difference $(\mathrm{P}>0.05)$ in SFA, MUFA, PUFA, $n-3$, or in the PUFA:SFA and $n-6: n-3$ ratios, when comparing the first and second Purunã generations to their ancestors.
\end{abstract}

KEY WORDS: beef, generation, cholesterol, CLA, fatty acids, meat

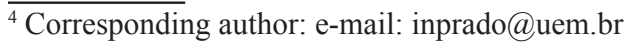




\section{INTRODUCTION}

Brazil has the largest commercial cattle herd in the world, with approximately 159 million animals and a production of approximately 8.2 million tons of carcass each year (Anualpec, 2007). From this total, about 30\% (2.4 million tons) is exported to several countries around the world.

The consumer market for beef has become increasingly demanding as a result of negative factors associated with meat production and quality. Among these factors are the undesirable relationships between beef consumption and heart disease, atherosclerosis, intestinal cancer, and obesity, among other diseases (Kwiterovich, 1997).

The fatty acid composition of meat (muscle and adipose tissue) is important for two main reasons: it determines nutritional value, and it affects various aspects of meat quality, including shelf-life and flavour. Nutritional value is determined in part by the ratio between saturated fatty acids (SFA) and polyunsaturated fatty acids (PUFA) in meat, as well as the balance between fatty acids of the $n-6$ and $n-3$ series. In general, a ratio of PUFA to SFA (termed P:S) above 0.45 and a ratio of $n-6: n-3$ below 4.0 are required in the diet to combat various "lifestyle diseases", such as coronary heart disease and cancers ( $\mathrm{Hu}, 2001)$.

Several factors in beef production affect fatty acid composition, including breed and diet. Breed affects the fat content in meat, and fat content itself is a determining factor for fatty acid profile (Prado et al., 2008b). Ruminants naturally consume a diet low in fat but high in PUFA, whether as fresh grass, conserved grass or the concentrate portion of the diet.

The State of Paraná, located in southern Brazil, features a milder climate as compared to other regions of the country. Consequently, researchers have been conducting studies since the 1980s on the crossbreeding between Zebu and European breeds, with the objective of increasing production (Perotto et al., 2000) and meat quality of bulls (Aricetti et al., 2008; Macedo et al., 2008; Prado et al., 2008a,b,c,d; Ducatti et al., 2009; Maggioni et al., 2009; Prado et al., 2009). After several stages of crossbreeding, an ideal crossbreeding ratio was found as the best adapted for the region. Initially, Nellore specimens were crossbred with Charolais, Angus, Caracu and Canchim cattle (Perotto et al., 200), giving rise to a breed Purunã. Purunã bulls are very well adapted to subtropical and tropical regions, and show good weight gain potential. Their carcass has better conformation and greater fat thickness than Zebu bulls. Genetics is the most important factor for fat deposition and composition. The detailed mechanisms of variation, however, is not fully understood, nor whether and how they can be manipulated. British breeds are well-known for their highly marbled meat, while the Zebu breeds contain less fat and more connective tissue (Rotta et al., 2009). In the warmer regions of Brazil, adapted breeds of cattle are primarily limited to Bos indicus cattle bred with Brazilian Nellore. 
This study was conducted to evaluate the effects of generation in the frame of the same breed on the Longissiums dorsi muscle chemical composition and fatty acid profile of its intramuscular fat.

\section{MATERIAL AND METHODS}

\section{Animals and management}

The Committee of Animal Production at the State University of Maringá approved this experiment, which was carried out at the Experimental Farm of the Agronomic Institute of Paraná (Brazil) and followed the guiding principles of biomedical research on animals .

Thirty-nine bulls (13-PUR1, 13-PUR2 and 13-PUR) were selected, all resulting from industrial crossbreeding and belonging to the experimental herd of the Agronomic Institute of Paraná (IAPAR).

\section{Diets}

The animals were set for young finishing bulls in feedlot with an average age of 10 months, with an initial liveweight of $236 \mathrm{~kg}$.

From birth to the age of 90 days, the calves followed their mothers in the annual winter pastures. After earty weaning (at 90 days of age), the calves were kept in pastures of Hemarthria altissima with concentrate supplementation $(1.5 \mathrm{~kg} /$ animal/day of a mixture made up of $25 \%$ soyabean meal, $73 \%$ cracked maize, $2 \%$ limestone and urea).

The animals were kept separate in individual pens $\left(5 \mathrm{~m}^{2}\right.$ for each animal), and fed twice a day. They were given access to a diet formulated to meet requirements for fattening beef cattle (NRC, 1996). The animals were fed maize silage ad libitum along with a concentrate made up of $25 \%$ soyabean meal, $73 \%$ cracked maize, and $2 \%$ salt, calculated as $1.2 \%$ of animal liveweight/day. The young bulls were weighed at the beginning of the experiment. Thereafter, they were weighed every 28 days, observing a 16-h fast of solids, accomplished by removing all feed at 4 p.m. on the day prior to weighing. Silage was provided ad libitum, with adjustments made according to the previous day's intake. Around 5 to $10 \%$ extra was left in the trough, in order not to limit intake. The experimental period lasted 180 days, during which the animals reached an average final liveweight of $464 \mathrm{~kg}$. The development of the thickness fat cover was monitored every 28 days after a period of adaptation for the animals, using an ultrasound device (Aloka 500 with a Ust-50493.5 transducer). After reaching $4 \mathrm{~mm}$ cover fat thickness and an average age of 16 months, the animals were slaughtered. 


\section{Slaughter protocol, sampling and analysis}

The animals were slaughtered at a commercial slaughterhouse $100 \mathrm{~km}$ away from the Lapa Research Farm, following the usual practices of the Brazilian beef industry. Thereafter, the carcasses were identified and weighed before chilling at $4^{\circ} \mathrm{C}$ for $24 \mathrm{~h}$. After chilling, the right part of the carcass was used to determine the quantitative characteristics. Twenty-four h later, samples from Longissimus dorsi muscle were taken by a complete cross-section between the $12^{\text {th }}$ and $13^{\text {th }}$ ribs. The fat cover was discarded and the muscle sample was frozen at $-20^{\circ} \mathrm{C}$ for further analyses. Laboratory analyses of beef were carried out about four months after sampling. The samples were thawed at $0^{\circ} \mathrm{C}$, ground, homogenized, and analysed in triplicate.

Beef moisture and ash contents were determined according to Cunniff (1998), crude protein according to the Kjeldahl method (Cunniff, 1998). Forage and beef intramuscular fat were extracted by the Bligh and Dyer method (1959) with a chloroform/methanol mixture. Fatty acids methyl esters (FAME) were prepared by triacylglycerol methylation according to ISO method 5509 (1978). All reagents and solvents used in the analysis were of analytical reagent quality and were purchased from Merck (Darmstadt, Germany).

Cholesterol analysis was carried out through direct saponification according to Al-Hasani et al. (1993). Cholesterol content was analysed in a 14-A gas chromatograph (Shimadzu, Japan), equipped with a flame ionization detector and a fused silica capillary column ( $25 \mathrm{~m}$ long, 0.25 - $\mathrm{mm}$ internal diameter, and $0.20 \mu \mathrm{m}$ Ohio Valley30). Injector, column, and detector temperatures were 260,280 and $280^{\circ} \mathrm{C}$, respectively. Ultra-pure gas fluxes (White Martins) of $1.5 \mathrm{ml} \mathrm{min}^{-1} \mathrm{H}_{2}$ as carrier gas, $30 \mathrm{ml}$

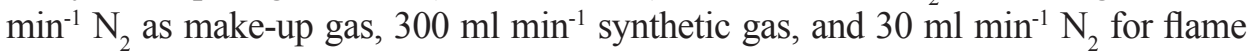
were used. The ratio of the areas of cholesterol and 5- $\alpha$ cholestane was plotted against the cholesterol concentration for injected volumes of $0.0,2.0,3.0,4.0$ and $5.0 \mu 1$. The curve obtained was used for cholesterol analysis in $\mathrm{mg} 100 \mathrm{~g}^{-1}$.

Fatty acids methyl esters (FAMEs) were analysed in a gas chromatograph (Varian, USA) equipped with flame ionization detector and fused silica capillary column CP-7420 Select FAME (100 m, $0.25 \mathrm{~mm}$, and $0.25 \mu \mathrm{m}$ film, Varian, USA). Fatty acids were identified by comparing sample relative retention times of FAME peaks with those of FAME standard-spiked samples (Sigma Chemical Co., St. Louis, MO, USA). The peak areas were determined by Star software (Varian).

\section{Experimental design and statistical analysis}

The experimental design with 3 treatments (PUR1, PUR2 and PUR) and 13 replications (animals) within each treatment was completely randomized. The 
data were submitted to a one-way analysis of variance using SAS statistical software (2000), according to the following mathematical model:

$$
\mathrm{Y}_{\mathrm{ij}}=\mu+\mathrm{t}_{\mathrm{i}}+\mathrm{e}_{\mathrm{ij}} \text {; }
$$

were: $Y_{i j}$ - observation of animal $j$, subjected to treatment $i ; \mu$ - overall constant; $t_{i}$ - treatment effect $i-1,2,3 ; e_{i j}$ - random error associated with each observation.

\section{RESULTS AND DISCUSSION}

Chemical composition. Moisture, ash, crude protein contents and total cholesterol were similar $(\mathrm{P}>0.05)$ among the three groups (Table 1). Average

Table 1. Chemical composition of the Longissimus dorsi muscle from young bulls of different genetic groups

\begin{tabular}{lccccc}
\hline \multirow{2}{*}{ Composition } & \multicolumn{3}{c}{ Genetic groups } & \multirow{2}{*}{ SE $^{4}$} & \multirow{2}{*}{$\mathrm{P}<\mathrm{F}$} \\
\cline { 2 - 4 } & PUR1 $^{1}$ & PUR2 & PUR $^{3}$ & & \\
\hline Water, \% & 73.2 & 74.3 & 74.5 & 0.52 & NS \\
Ash, \% & 1.01 & 0.97 & 0.96 & 0.02 & NS \\
Crude protein, \% & 23.1 & 22.4 & 21.8 & 0.57 & NS \\
Intramuscular fat, \% & $2.68^{\mathrm{b}}$ & $3.20^{\mathrm{b}}$ & $5.60^{\mathrm{a}}$ & 0.64 & 0.05 \\
Total cholesterol $^{5}$ & 41.7 & 40.7 & 43.9 & 2.34 & $\mathrm{NS}$ \\
\hline
\end{tabular}

${ }^{1}$ first-generation Purunã; ${ }^{2}$ second-generation Purunã; ${ }^{3}$ pure breed; ${ }^{4}$ standart error; ${ }^{5} \mathrm{mg} / 100 \mathrm{~g}$ of muscle; NS - non-significant

moisture content was $74.0 \%$, which is similar to other studies (Moreira et al., 2003; Prado et al., 2009; Rotta et al., 2009). Padre et al. (2006) found $73.7 \%$ of moisture in $1 / 2$ Nellore vs $1 / 2$ Aberdeen Angus. Variations in moisture percentages occur when there is a variation in lipid percentages in the Longissimus dorsi muscle. The higher percentage of intramuscular fat does the water get lower (Prado et al., 2008a,b).

The average ash percentage was $0.98 \%$. Padre et al. $(2006,2007)$ observed ash percentages similar to those in this study. Thus, ash percentage is little influenced by diet or genetic group (Moreira et al., 2003; Padre et al., 2007). Ash is important to the supply of zinc and iron, which are of great nutritional importance to humans.

The average protein percentage in the Longissimus dorsi muscle was $23.7 \%$. In the literature (Marques et al., 2006; Padre et al., 2007), there are reports of average crude protein percentages in Longissimus dorsi muscle varying between 21 and $24 \%$. Thus, it can be concluded that the genetic group would not alter protein percentage in the muscles of bovines. Protein is important in meat, as it features a peptide known as carnitine, which plays an essential role in metabolism 
by facilitating energy production from fat reserves. When ready for human consumption, $100 \mathrm{~g}$ of beef supply about $50 \%$ of the protein needs for a $60-\mathrm{kg}$ adult (HSMO, 1994).

Intramuscular fat was greater $(\mathrm{P}<0.05)$ in the Longissimus dorsi muscle of animals from the PUR genetic group, in comparison to animals from the PUR1 and PUR2 genetics groups. However, there was no observed difference $(\mathrm{P}>0.05)$ in the Longissimus dorsi muscle of animals from the PUR1 and PUR2 genetic groups. In general, intramuscular fat in the Longissimus dorsi muscle of bulls finished in feedlot is close to 3\% (Padre et al., 2006, 2007; Kazama et al., 2008). As such, the animals from the PUR genetic group featured levels over those recommended by the English Health Department (HMSO, 1994). However, the beef from these PUR specimens is considered very tender exactly because of their high lipid levels, as the two characteristics are proportionally similar.

The average cholesterol levels found were $42.1 \mathrm{mg} / 100 \mathrm{~g}$ of muscle. Higher values were obtained by Wheeler et al. (1987) while evaluating the cholesterol concentration in the Longissimus dorsi muscle of Chianina or Hereford vs Aberdeen Angus crossbreeds, for which they found a concentration of $63.3 \mathrm{mg} / 100 \mathrm{~g}$ of muscle. In that study, it was discovered that the cholesterol levels were highest in animals slaughtered at $455 \mathrm{~kg}(82.4 \mathrm{mg} / 100 \mathrm{~g}$ of muscle). However, young cattle

Table 2. Fatty acid profile of the Longissimus dorsi muscle of young bulls of different genetic groups

\begin{tabular}{|c|c|c|c|c|c|}
\hline \multirow{2}{*}{ Fatty acids } & \multicolumn{3}{|c|}{ Genetic groups } & \multirow{2}{*}{$\mathrm{SE}^{4}$} & \multirow{2}{*}{$\mathrm{P}<\mathrm{F}$} \\
\hline & PUR1 $^{1}$ & PUR2 $^{2}$ & $\mathrm{PUR}^{3}$ & & \\
\hline $14: 0$ & $1.64^{\mathrm{b}}$ & $2.43^{\mathrm{a}}$ & $2.13^{\mathrm{a}}$ & 0.19 & 0.05 \\
\hline $14: 1 n-7$ & $0.15^{\mathrm{b}}$ & $0.17^{\mathrm{a}}$ & $0.19^{\mathrm{a}}$ & 0.03 & 0.05 \\
\hline $16: 0$ & $26.7^{b}$ & $29.4^{\mathrm{a}}$ & $27.4^{\mathrm{ab}}$ & 0.85 & 0.05 \\
\hline $16: 1 n-7$ & 2.15 & 2.51 & 2.53 & 0.28 & NS \\
\hline $17: 0$ & 0.59 & 0.61 & 0.55 & 0.05 & NS \\
\hline $18: 1 t-11$ & 0.88 & 0.76 & 0.78 & 0.30 & NS \\
\hline $17: 1 n-9$ & 0.49 & 0.48 & 0.51 & 0.05 & NS \\
\hline 18:0 & 19.6 & 17.5 & 18.3 & 1.35 & NS \\
\hline $18: 1 n-9$ & 40.9 & 40.6 & 42.9 & 1.15 & NS \\
\hline $18: 2 n-6$ & 4.42 & 3.52 & 3.2 & 0.62 & NS \\
\hline $18: 3 n-6$ & 0.13 & 0.14 & 0.17 & 0.05 & NS \\
\hline $18: 3 n-3$ & 0.19 & 0.11 & 0.16 & 0.04 & NS \\
\hline CLA & 0.17 & 0.18 & 0.25 & 0.04 & NS \\
\hline $20: 4 n-6$ & 1.21 & 0.84 & 0.71 & 0.23 & NS \\
\hline $22: 0$ & 0.32 & 0.22 & 0.27 & 0.09 & NS \\
\hline $20: 5 n-3$ & 0.13 & 0.15 & 0.15 & 0.05 & NS \\
\hline $22: 5 n-3$ & 0.14 & 0.13 & 0.12 & 0.01 & NS \\
\hline $22: 6 n-3$ & $0.23^{\mathrm{a}}$ & $0.17^{\mathrm{b}}$ & $0.04^{\mathrm{c}}$ & 0.05 & 0.05 \\
\hline
\end{tabular}

${ }^{1}$ first-generation Purunã; ${ }^{2}$ second-generation Purunã; ${ }^{3}$ pure breed; ${ }^{4}$ standart error; NS - nonsignificant 
feature low total cholesterol levels in the Longissimus dorsi muscle (Padre et al., 2006, 2007; Kazama et al., 2008).

Fatty acid profile. Table 2 shows the fatty acid profile of the Longissimus dorsi muscle. Animals from the PUR2 and PUR genetic groups featured higher $(\mathrm{P}<0.05)$ percentages of 14:0 (myristic acid) and 14:1 $n-7$ as compared to specimens from the PUR1 genetic group. Furthermore, no difference was observed for these two fatty acids between PUR2 and PUR animals. The percentage of 16:0 (palmitic acid) was lower $(\mathrm{P}<0.05)$ in PUR1 and higher $(\mathrm{P}<0.05)$ in PUR2 animals. The percentage of 18:2 cis-9 trans-11 (conjugated linoleic acid - CLA) was similar $(\mathrm{P}>0.05)$ among genetic groups. The term CLA refers to a mixture of linoleic acid isomers, of which the 18:2 cis- 9 trans-11 form is the one most commonly found in the meat of ruminants, and is important because of its many beneficial properties for human health, being anticarcinogen, antiatherogenic, antidiabetic (type II) and an immunomodulator (Bauman and Griinari, 2001).

Animals from the PUR1 genetic group featured a higher $(\mathrm{P}<0.05)$ percentage of 22:6n-3 (cervonic acid - DHA). DHA is considered essential in the formation of nerve and eye tissues, in which it plays an especially important role in the early stages of development before and after birth, as well as on the mother's needs during gestation and lactation.

Among all fat components, the ones that offer the greatest health risks to humans are saturated fatty acids. However, not all fatty acids act in the same manner 14:0 (myristic acid), 16:0 (palmitic acid) and 17:0 (margaric acid) raise the levels of low density lipoprotein-cholesterol in the bloodstream.

As ruminant diets contain low fat concentrations, the majority of the adipose tissue is synthesized from lipogenesis. Fatty acids are elongated up to 18:0 and converted into $18: 1$ by desaturation. As the adipose tissue increases, the deposition of 18:1 content also increases, and that of 18:2 is reduced.

Oleic acid raises human HDL-cholesterol (high density lipoprotein) and lowers LDL-cholesterol (low density lipoprotein) concentration in the blood. Studies have demonstrated a strong positive relationship between LDL-cholesterol levels and human cardiovascular diseases, while HDL-cholesterol has an inverse relationship with the risk of cardiovascular diseases (Kwiterovich, 1997).

Table 3 shows that the percentages of saturated fatty acids (SFA), monounsaturated fatty acids (MUFA), polyunsaturated fatty acids (PUFA), n-6 and $n-3$ fatty acids, as well as PUFA:SFA and $n-6: n-3$ ratios for lipid in the Longissimus dorsi muscle were similar $(\mathrm{P}>0.05)$ among animals from the different genetic groups. Although the animal diet contained high levels of PUFA, the meat featured high values of SFA due to biohydrogenation in the rumen. The ratio of PUFA:SFA fatty acids plays an important role in reducing the risk of coronary heart disease; however, the optimal balance between these two classes of fatty acids is still a matter of debate $(\mathrm{Hu}, 2001)$. 
Table 3. Proportion (\%) of saturated fatty acids (SFA), monounsaturated fatty acids (MUFA), polyunsaturated fatty acids (PUFA), $n-6$ fatty acids, $n-3$ fatty acids, PUFA:SFA and $n-6: n-3$ ratios of the Longissimus dorsi muscle of young bulls

\begin{tabular}{lccccc}
\hline \multirow{2}{*}{ Fatty acids } & \multicolumn{3}{c}{ Genetic groups } & \multirow{2}{*}{ SE $^{4}$} & \multirow{2}{*}{$\mathrm{P}<\mathrm{F}$} \\
\cline { 2 - 4 } & PUR1 $^{1}$ & PUR2 $^{2}$ & PUR $^{3}$ & & \\
\hline SFA & 48.3 & 48.8 & 46.7 & 1.13 & NS \\
MUFA & 44.6 & 46.9 & 44.5 & 0.84 & NS \\
PUFA & 6.50 & 6.17 & 7.40 & 0.47 & NS \\
$n-6$ & $4.51^{\mathrm{b}}$ & $4.08^{\mathrm{b}}$ & $5.76^{\mathrm{a}}$ & 0.63 & 0.05 \\
$n-3$ & 0.57 & 0.47 & 0.68 & 0.09 & $\mathrm{NS}$ \\
PUFA:SFA & 0.13 & 0.13 & 0.15 & 0.01 & $\mathrm{NS}$ \\
$n-6: n-3$ & 9.34 & 10.7 & 8.63 & 1.24 & $\mathrm{NS}$ \\
\hline
\end{tabular}

${ }^{1}$ first-generation Purunã, ${ }^{2}$ second-generation Purunã, ${ }^{3}$ pure breed, ${ }^{4}$ standard error, NS - nonsignificant

Laborde et al. (2001) recommend the intake of at most $11 \mathrm{~g}$ of saturated fatty acids, a minimum of $3.300 \mathrm{mg}$ PUFA $n-6$ and at least $500 \mathrm{mg}$ of PUFA $n-3$ per $1,000 \mathrm{kcal}$ of energy.

The $n-6: n-3$ ratio recommended by HSMO (1994) is $4-10: 1$. The ratio obtained in this experiment was around 9:1, which meets the recommendations set by Laborde et al. (2001). Similar or higher values are generally observed in the meat of confined animals, while the opposite is found in animals raised in pasture systems (Padre et al., 2007).

The percentages of MUFA and PUFA at 45.3 and $6.69 \%$, respectively, represent an important contribution to lower levels of bad cholesterol (LDL) and raising good cholesterol (HDL) (Kwiterovich, 1997).

The $n-3$ and $n-6$ fatty acids are precursors of eicosanoids (protaglandin, tromboxanes and leukotrienes), which act in controlling a variety of body functions, including blood pressure, heart rate, vascular dilation, blood coagulation, lipolysis and immunologic responses.

According to De Smet et al. (2003), the PUFA:SFA ratio is influenced mainly by genetics, particularly in the different adipose levels of the animal, with little effect caused by nutrition. The secondary effect of nutrition in the PUFA:SFA ratio is particularly important for ruminants, given that a part of the unsaturated fatty acids in their diet is hydrogenated in the rumen, in contrast to what happens in monogastric species.

However, the $n-6: n-3$ ratio may be influenced by the fatty acid composition in animal diets, with the inclusion of $n-3$ sources in the diet of animals increasing total $n-3$ content, along with a decrease in the deposition of intramuscular $n-6$ fatty acids; as the supply of $n-6$ is lowered, the $n-6: n-3$ ratio decreases. Ruminants finished on pasture systems have an $n-6: n-3$ ratio below two (Padre et al., 2003, 
2007), while for ruminants finished in feedlots on a high grain diet, this ratio stays around 6 to 10 (Kazama et al., 2008).

\section{CONCLUSIONS}

Animals from the Purunã PUR1 and PUR2 genetic groups produced beef of high quality when compared to other genetic groups, in terms of chemical composition and fatty acid profile. Animals from the PUR genetic group featured higher lipid levels as compared to the other genetic groups.

\section{REFERENCES}

Al-Hasani S.M., Hlavac J., Carpenter M.W., 1993. Rapid determination of cholesterol in single and multi-component prepared foods. J. Assn. Anal. Chem. Int. 76, 902-906

Anualpec, 2007. Annual of Brazilian Livestock. São Paulo: FNP Institut, pp. 368

AOAC, 1998. Association of Official Analytical Chemists, Official Methods of Analysis. 16 $6^{\text {th }}$ Edition. Arlington, VA

Aricetti J.A., Rotta P.P., Prado R.M., Perotto D., Moletta J.L., Matsushita M., Prado, I.N., 2008. Carcass characteristics, chemical composition and fatty acid profile of Longissimus muscle of bulls and steers finished in a pasture system. Asian-Austr. J. Anim. Sci. 21, 1441-1448

Bauman D.E., Griinari J.M., 2001. Regulation and nutritional manipulation of milk fat: low-fat milk syndrome. Livest. Prod. Sci. 70, 15-29

Bligh E.G., Dyer W.J., 1959. A rapid method of total lipid extraction and purification. Can. J. Biochem. Physiol. 37, 911-917

De Smet S., Webb E.C., Claeys E., Uytterhaegen L., Demeyer D.I., 2000. Effect of dietary energy and protein levels on fatty acid composition of intramuscular fat in double-muscled Belgian Blue bulls. Meat Sci. 56, 73-79

Ducatti T., Prado I.N., Rotta P.P., Prado R.M., Perotto D., Maggioni D., Visentainer J., 2009. Chemical composition and fatty acid profile in crossbred (Bos Taurus vs. Bos indicus) young bulls finished in a feedlot. Asian-Austr. J. Anim. Sci. 22, 433-439

HMSO - England, 1994. Department of Health. Nutritional Aspects of Cardiovascular Disease. Report on Health and Social Subjects 46. London, pp. 37-46

Hu F.B., 2001. The balance between $\omega-6$ and $\omega-3$ fatty acids and the risk of coronary heart disease. Nutrition 17, 741-742

ISO - International Organization for Standardization, 1978. Animal and Vegetable Fats and Oils - Preparation of Methyl Esters of Fatty Acids. Method ISO 5509

Kazama R., Zeoula L.M., Prado I.N., Silva D.C., Ducatti T., Matsushita M., 2008. Quantitative and qualitative carcass characteristics of heifers fed different energy sources on a cottonseed hulls and soybean hulls based diet. Braz. J. Anim. Sci. 37, 350-357

Kwiterovich P.O., 1997. The effect of dietary fat, antioxidants, and pro-oxidants on blood lipids, lipoproteins, and atherosclerosis. J. Amer. Diet. Assn. 97, Suppl., 31-41

Laborde F.L., Mandell I.B., Tosh J.J., Wilton J.W., Buchanan-Smith J.G., 2001. Breed effects on growth performance, carcass characteristics, fatty acid composition, and palatability attributes in finishing steers. J. Anim. Sci. 79, 355-365 
Macedo L.M., Prado I.M., Prado J.M., Rotta P.P., Prado R.M., Souza N.E., Prado I.N., 2008. Chemical composition and fatty acids profile of five carcass cuts of crossbred heifers finished in feedlot. Semina 29, 599-610

Maggioni D., Marques J.A., Perotto D., Rotta P.P., Ducatti T., Matsushita M., Silva R.R., Prado I.N., 2009. Bermuda grass hay or sorghum silage with or without yeast addition on performance and carcass characteristics of crossbred young bulls finished in feedlot. Asian-Austr. J. Anim. Sci. 22, 206-215

Marques J.A., Prado I.N, Moletta J.L., Prado I.M., Prado J.M., Macedo L.M.A., Souza N.E., Matsuhita M., 2006. Carcass and meat traits of feedlot finished heifers submitted to surgical or mechanical anoestrous. Braz. J. Anim. Sci. 35, 1514-1522

Moreira F.B., Prado I.N., Cecato U., Wada F.Y., Nascimento W.G., Souza N.E., 2003. Protein mineral salt supplements for growing and finishing beef cattle in star grass (Cynodon plectostachyrus Pilger), in the winter. Braz. J. Anim. Sci. 32, 449-455

NRC, 1996. Nutrient Requirements of Beef Cattle. National Research Council. 7th Edition. National Academy Press. Washington, DC

Padre R.G., Aricetti J.A., Gomes S.T.M., Goes R.H.T.B., Moreira F.B., Prado I.N., Visentainer J.V., Souza N.E., Matsushita M., 2007. Analysis of fatty acids in Longissimus dorsi muscle of steers of different genetic breeds finished in pasture systems. Livest. Sci. 110, 57-63

Padre R.G., Aricetti J.A., Moreira F.B., Mizubuti I.Y., Prado I.N., Visentainer J.V., Souza N.E., Matsushita M., 2006. Fatty acid profile and chemical composition of Longissimus dorsi muscle of bovine steers and bulls finished in pasture system. Meat Sci. 74, 242-248

Perotto D., Cubas A.C., Moletta J.L., Lesskiu C., 2000. Feed intake and feed:gain ratio of Charolais, Caracu and reciprocal crossbred males in finished in feedlot. Pesq. Agropec. Bras. 35, 2511-2520

Prado I.N., Aricetti J.A., Rotta P.P., Prado R.M., Perotto D., Visentainer J.V., Matsushita M., 2008d. Carcass characteristics, chemical composition and fatty acid profile of the Longissimus muscle of bulls (Bos Taurus indicus vs. Bos Taurus Taurus) finished in pasture systems. Asian-Austr. J. Anim. Sci. 21, 1449-1457

Prado I.N., Ito R.H., Prado J.M., Prado I.M., Rotta P.P., Matsushita M., Visentainer J.V., Silva R.R., 2008a. The influence of dietary soyabean and linseed on the chemical composition and fatty acid profile of the Longissimus muscle of feedlot-finished bulls. J. Anim. Feed Sci. 17, 307-317

Prado I.N., Prado R.M., Rotta P.P., Visentainer J.V., Moletta J.L., Perotto D., 2008b. Carcass characteristics and chemical composition of the Longissimus muscle of crossbred bulls (Bos taurus indicus vs Bos taurus taurus) finished in feedlot. J. Anim. Feed Sci. 17, 295-306

Prado I.N., Rotta P.P., Prado R.M., Visentainer J.V., Moletta J.L., Perotto D., 2008c. Carcass characteristics and chemical composition of the Longissimus muscle of Purunã and 1/2 Puruna vs. 1/2 Canchin bulls. Asian-Austr. J. Anim. Sci. 21, 1296-1302

Prado R.M., Prado I.N., Marques J.A., Rotta P.P., Visentainer J.V., Silva R.R., Silva N.E., 2009. Meat quality of Longissimus muscle of bulls and steers (1/2 Nellore vs $1 / 2$ Simmenthal) finished in feedlot. J. Anim. Feed Sci. 18, 221-230

Rotta P.P., Prado I.N., Prado R.M., Moletta J.L., Silva R.R., Perotto D., 2009. Carcass characteristics and chemical composition of the Longissimus muscle of Nellore, Caracu and Holstein-friesian bulls finished in a feedlot. Asian-Austr. J. Anim. Sci. 22, 598-604

SAS, 2000. Institute Sas $/$ Stat $^{\mathbb{R}}$. User's Guide: Statistics, Version 8.1. $4^{\text {nd }}$ Edition. Cary, NC

Wheeler T.L., Davis G.W., Stoecker B.J., Harmon C.J., 1989. Cholesterol concentration of Longissimus dorsi muscle, subcutaneous fat and serum of two beef cattle breed types. J. Anim. Sci. 67, 2669-2676 